Article

\title{
Identification and Quantification of Volatile Compounds Found in Vinasses from Two Different Processes of Tequila Production
}

\author{
Elizabeth Rodríguez-Félix ${ }^{1}$, Silvia Maribel Contreras-Ramos ${ }^{1}$ (D), Gustavo Davila-Vazquez ${ }^{1,+}$, \\ Jacobo Rodríguez-Campos ${ }^{2, *}$ and Erika Nahomy Marino-Marmolejo ${ }^{3, * \text { (D) }}$ \\ 1 Environmental Technology Unit, Center for Research and Assistance in Technology and Design of the State \\ of Jalisco (CIATEJ), Guadalajara 44270, Jalisco, Mexico; elrodriguez_al@ciatej.edu.mx (E.R.-F); \\ smcontreras@ciatej.mx (S.M.C.-R); gdv@ciatej.mx (G.D.-V) \\ 2 Analytical and Metrological Unit, Center for Research and Assistance in Technology and Design of the State \\ of Jalisco (CIATEJ), Guadalajara 44270, Jalisco, Mexico \\ 3 Medical and Pharmaceutical Unit, Center for Research and Assistance in Technology and Design of the State \\ of Jalisco (CIATEJ), Guadalajara 44270, Jalisco, Mexico \\ * Correspondence: jarodriguez@ciatej.mx (J.R.-C.); emarino@ciatej.mx (E.N.M.-M.); \\ Tel.: +52-333-345-5200 (ext. 1671) (E.N.M.-M.) \\ $+\quad$ Deceased, 13 March 2017.
}

Received: 18 January 2018; Accepted: 11 February 2018; Published: 26 February 2018

\begin{abstract}
Vinasses are the main byproducts of ethanol distillation and distilled beverages worldwide and are generated in substantial volumes. Tequila vinasses (TVs) could be used as a feedstock for biohydrogen production through a dark fermentative (DF) process due to their high content of organic matter. However, TV components have not been previously assayed in order to evaluate if they may dark ferment. This work aimed to identify and quantify volatile compounds (VC) in TV and determine if the VC profile depends upon the type of production process (whether the stems were initially cooked or not). TVs were sampled from 3 agave stems with a not-cooking (NC) process, and 3 agave stems with a cooking $(C)$ process, and volatile compounds were determined by gas chromatography coupled with mass spectrometry (GC-MS). A total of 111 volatile compounds were identified, the TV from the cooking process (C) showed the higher presence of furanic compounds (furfural and 5-(hydroxymethyl) furfural) and organic acids (acetic acid and butyric acid), which have been reported as potential inhibitors for DF. To our knowledge, this is the first description of the VC composition from TVs. This study could serve as a base for further investigations related to vinasses from diverse sources.
\end{abstract}

Keywords: stillage; volatile compounds; tequila; inhibitors; dark fermentative

\section{Introduction}

Vinasses are produced as byproducts of the fermentation and distillation of ethanol [1,2] from sugarcane (Saccharum officinarum L.) in South America [3], beet molasses (Beta vulgaris ssp. vulgaris var. altissima Döll) in Europe [4,5], or from the distillation of fermented beverages, such as mezcal, bacanora, and tequila in Mexico [6-8]. Large quantities of vinasses are produced worldwide; on average, 12-15 L vinasses are obtained for each liter of ethanol produced [9]. According to the Renewable Fuel Association (http:/ / www.ethanolrfa.org), global ethanol production was 25.7 billions of gallons in 2016, leading to approximately $2.56 \times 10^{12} \mathrm{~L}$ of vinasses, which are released without any treatment into agricultural soils or water bodies $[9,10]$. Regardless of the ethanol production process or the sugar source, these may have similar characteristics. They are complex wastewaters and have high 
biological oxygen demand (BOD) and chemical oxygen demand (COD), 16-45 g/L and 26-91 g/L, respectively, $\mathrm{pH}$ ranges from 3 to 5 , high concentrations of suspended solids ( $2-8.4 \mathrm{~g} / \mathrm{L}$ ), volatile solids (1.1-9 g/L), and phenols $(0.04-0.08 \mathrm{~g} / \mathrm{L})$. Occasionally they may contain heavy metals, and display a dark brown color [2,4,11-13]. The toxic and recalcitrant nature of this effluent can produce negative environmental impacts like anoxia, eutrophication, and the death of aquatic microorganism and wildlife $[13,14]$.

Tequila distilleries are one of the most important agro-industries [15] producing a popular alcoholic beverage called tequila, which is obtained from the fermentation of hydrolyzable sugars from the stems of Agave tequilana Weber var. Azul [10,14]. The agave juice or "mieles de agave" (as locals call it) extraction process requires fructans to be transformed by thermic treatments into fermentable sugars (fructose and glucose), so they can be subsequently fermented by yeast [16,17]. Currently, two processes are used to accomplish sugar hydrolysis. Some distilleries employ traditional methods, i.e., (cooking (C) of agave stems, whereby the mature stems (with no leaves) of agave, so-called "piñas", are cooked in ovens or autoclaves with steam injection $\left(0.5-1.4 \mathrm{~kg} / \mathrm{cm}^{2}\right)$ at $95-120^{\circ} \mathrm{C}$ for approximately $48 \mathrm{~h}$ or $8-12 \mathrm{~h}$. Once the agave stems are cooked, they are transferred on conveyor belts to a mill with rotatory knives where they are shredded and washed under pressure with potable water to dissolve the sugars. Finally, the stems are placed in a press to extract the agave juice, containing hydrolyzable sugars, soluble, and insoluble compounds which are generated during the cooking process [6,18-20]. However, most producers use a "not-cooking" (NC) process, i.e., [20,21], they used equipment called a "diffuser" to obtain the raw agave juice with hot water $\left(80^{\circ} \mathrm{C}\right)$ directly from previously shredded raw agave stems. Afterwards, the raw agave juice is hydrolyzed through heat $\left(80-85^{\circ} \mathrm{C}\right)$ in acidic conditions ( $\mathrm{pH} 1.8-3)$ and thermal conditions $[18,20,22]$. The agave juice obtained either from cooking or not-cooking are submitted to a fermentation process, where hydrolizable sugars are biotransformed to ethanol, carbon dioxide, and other organoleptic compounds such as volatile compounds (esters, aldehydes, ketones, and furans, among others) [23]. Once fermentation is completed, the fermented juice, "must", is transferred to a distiller, where two tandem distillations are performed to obtain tequila. After the final distillation, vinasses are generated as the residual liquid [22,23].

Both processes (cooking or not-cooking the agave stems) might influence the composition of distillation wastewater. Like other vinasses, tequila vinasses (TVs) can also be used as a feedstock for a dark fermentative process (DF) to produce hydrogen, due to its high organic matter content. However, the vinasses' organic matter is not entirely used for biohydrogen production during DF [7,24-26]. Nevertheless, there is not sufficient information about the presence of volatile or complex organic compounds in vinasses, and even less in tequila vinasses.

Some work has tried to determine the composition of molasses and sugarcane vinasses to predict their toxicity. Fagier et al. [27] identified phenolic compounds and some carboxylic acids as volatile compounds in sugarcane vinasses, some of which are highly toxic for Daphnia magna (IC50 = $0.9 \mathrm{mg} / \mathrm{L}$ ). Additionally, Lima et al. [28] identified some fatty acids, alcohols, and esters in hydrolyzed sugarcane vinasses.

As has been previously observed in sugarcane vinasses, volatile compounds, like furans (furfural, 5-(hydroxymethyl) furfural and, methyl-2-furoate), organic acids (acetic acid, butyric acid, propanoic acid, and pentanoic acid) and phenols (2,5-di-tert-butylphenol, eugenol, guaiacol and, 4-ethyl-3-methoxy phenol) have been found also in tequila and cooked agave juice $[27,29,30]$. This suggests that those or similar volatile compounds might be present in tequila vinasses. Moreover, some of these volatile compounds are toxic and might inhibit subsequent biological treatments of vinasses, like the DF process to produce hydrogen [31-34]. More detailed knowledge on vinasse composition would help scientists to develop more efficient uses of vinasses, and reduce their adverse effects.

There is still a gap in the knowledge of vinasse composition from various sources regarding the presence of volatile compounds, which could inhibit downstream processes or uses, such as biohydrogen production. Furthermore, the extent of the effect of the initial process for tequila 
production (cooking or not-cooking of agave stems) on the final vinasse composition have not yet been described. Thus, the aim of this work was to identify and quantify the profile of volatile compounds in vinasses, obtained from two different tequila-production processes: (i) cooking $(\mathrm{C})$ and not-cooking (NC) agave stems.

\section{Results}

\subsection{Identification and Concentration of Volatile Compounds}

The vinasse samples have different profiles and volatile compound concentration. It was possible to identify 104 compounds belonging to different chemical families (Table 1). The most frequent chemical families were alcohols (20), acids (16), and furans (11); also, alkanes, aldehydes, esters, ketones, phenols, and pyrans were identified.

\subsubsection{Organic Acids}

The organic acids detected in tequila vinasses were: acetic (1), isobutyric (2), butyric (3), valeric (4), caproic (6), oenanthic (7), caprylic (8), lauric (12), palmitic (15) acids, and others (Table 1).

Acetic acid was found in all studied vinasses, its concentration (13.20-181.25 mg/L) showed significant differences $(p<0.05)$, between $C$ and NC processes, where the vinasse $C 2$ showed the highest acetic acid concentration $(181.25 \mathrm{mg} / \mathrm{L})$. Butyric acid was identified in all samples too, with significant differences $(p<0.05)$ among vinasse samples, ranging from 7.84 to $38.86 \mathrm{mg} / \mathrm{L}$, NC2 vinasse showed the highest concentration than other vinasses (Figure 1).

a) Organic acids

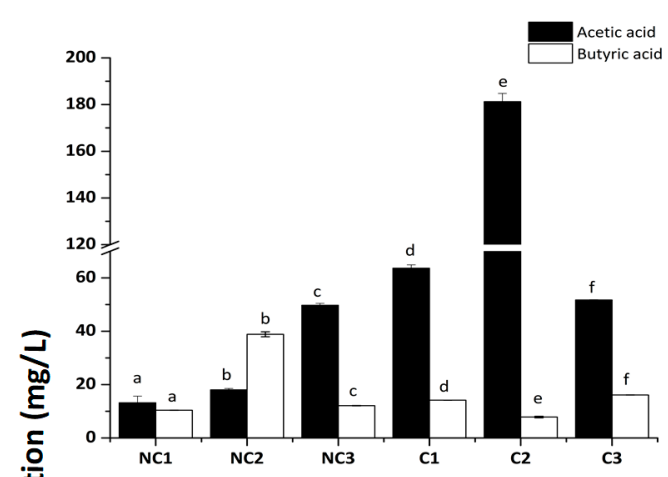

c) Furanic compounds and ketones

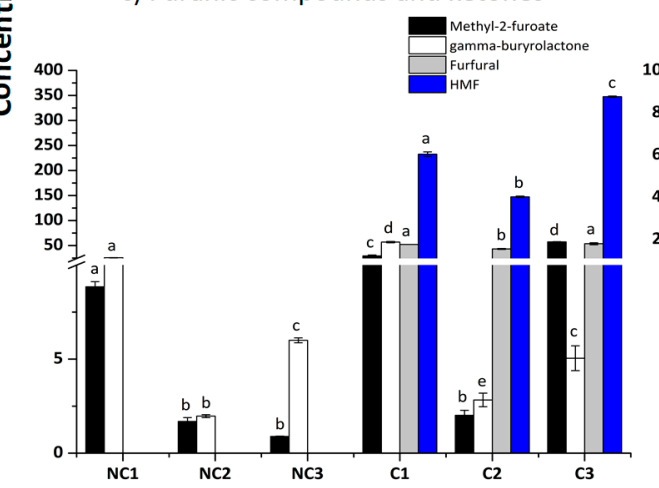

b) Alcohols

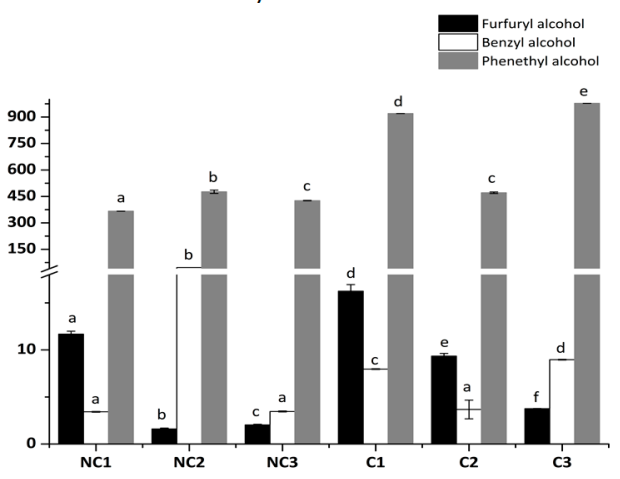

d) Phenols compounds

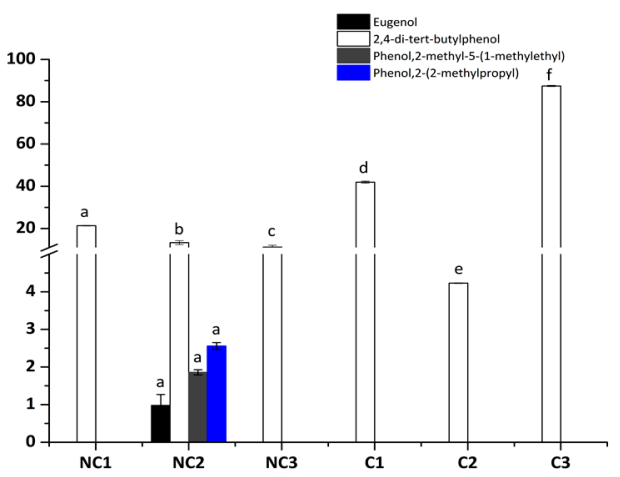

Tequila vinasses

Figure 1. The total concentration of volatile compounds found in tequila vinasses from both processes (not-cooking (NC) and cooking (C)) by functional group. Bars represents mean \pm standard deviation. Different lowercase letters indicate significant differences for each compound among the analyzed vinasses $(p<0.05$, an analysis of variance (ANOVA)). 
Table 1. Volatile compounds identified in tequila vinasses, using gas chromatography coupled with mass spectrometry (GC-MS).

\begin{tabular}{|c|c|c|c|c|c|c|c|}
\hline Number & Compound & $\begin{array}{l}\text { Retention } \\
\text { Time (min) }\end{array}$ & Odor Quality a & $\begin{array}{l}\text { Kovats Retention } \\
\text { Index }{ }^{\mathrm{b}}\end{array}$ & Sample Found & Identification $^{c}$ & Reference \\
\hline \multicolumn{8}{|c|}{ Acids } \\
\hline 1 & Acetic acid & 11.89 & sour, astringent, viniegra & $1680^{\mathrm{b}}$ & All samples & MS, IK, STD & Wanakhachornkrai \& Lertsiri (2003) \\
\hline 2 & Isobutyric acid & 14.48 & rancid, butter, cheese, hammy & $>1500^{\mathrm{b}}$ & $\mathrm{NC} 1, \mathrm{NC} 2, \mathrm{NC} 3, \mathrm{C} 1, \mathrm{C} 3$ & MS, IK & Chuenchomrat et al. (2008) \\
\hline 3 & Butyric acid & 16.06 & - & $1720^{\mathrm{b}}$ & All samples & MS, IK, STD & Wanakhachornkrai \& Lertsiri (2003) \\
\hline 4 & Isovaleric acid & 16.43 & sweat, acid, rancid & $1864^{\mathrm{b}}$ & All samples & MS, IK, STD & Jerković et al. (2012) \\
\hline 5 & Valeric acid & 19.4 & sweet & - & NC2 & MS, IK, STD & Chung et al. (1993) \\
\hline 6 & Caproic acid & 22.5 & $\begin{array}{l}\text { cheese, oil, pungent, sour, rancid, } \\
\text { sickening }\end{array}$ & - & All samples & MS, IK & Wanakhachornkrai \& Lertsiri (2003) \\
\hline 7 & Oenanthic acid & 25.82 & rancid, sour, sweat & - & NC2 & MS & - \\
\hline 8 & Caprylic acid & 29.09 & cheese, fat, grass, oil & - & $\mathrm{NC} 1, \mathrm{NC} 2, \mathrm{NC} 3, \mathrm{C} 1, \mathrm{C} 3$ & - & - \\
\hline 9 & Benzoic acid, hexahydro- & 29.79 & fruit & - & NC2 & MS & - \\
\hline 10 & 9-Decenoic acid & 37.15 & - & - & NC2 & MS & - \\
\hline 11 & Hendecanoic acid & 41.25 & oil & - & $\mathrm{NC} 1, \mathrm{NC} 3$ & MS & - \\
\hline 12 & Lauric acid & 41.5 & metal & - & NC2 & MS & - \\
\hline 13 & 3-Methyl-benzoic acid & 42.56 & - & - & All samples & MS & - \\
\hline 14 & Benzenepropanoic acid & 44.48 & - & - & $\mathrm{NC} 2, \mathrm{C} 2$ & MS & - \\
\hline 15 & Palmitic acid & 51.775 & - & - & All samples & MS & - \\
\hline 16 & Myristic acid & 57.6 & - & - & All samples & MS & - \\
\hline \multicolumn{8}{|c|}{ Esters } \\
\hline 17 & Ethyl orthoformate & 7.07 & - & $1465^{\mathrm{b}}$ & $\mathrm{NC} 2, \mathrm{C} 2$ & MS & - \\
\hline 18 & Ethyl butanoate & 8.88 & - & $>1493^{b}$ & $\mathrm{C} 2$ & MS, IK & Wanakhachornkrai \& Lertsiri (2003) \\
\hline 19 & 1,1-Dimethylpropyl ester, pentanoic acid & 9.38 & sweet & $>1500^{\mathrm{b}}$ & $\mathrm{NC1}, \mathrm{NC3}$ & MS & - \\
\hline 20 & Ethyl lactate & 9.88 & pungent, rancid, soy & - & $\mathrm{NC} 2, \mathrm{C} 1, \mathrm{C} 2, \mathrm{C} 3$ & MS, IK & Wanakhachornkrai \& Lertsiri (2003) \\
\hline 21 & Methylthiohexanoate & 17.11 & - & $>1500^{\mathrm{b}}$ & $\mathrm{NC} 2$ & MS & - \\
\hline 22 & Diethyl succinate & 17.4 & - & - & NC2 & MS & - \\
\hline 23 & Ethyl acetate & 19.37 & aromatic, brandy, grape & - & $\mathrm{C} 2$ & MS, IK & - \\
\hline 24 & Methyl salicylate & 20.43 & - & - & NC2 & MS & - \\
\hline 25 & Allyl phenylacetate & 21.62 & floral & - & $\mathrm{C} 2$ & MS & - \\
\hline 26 & Ethyl palmitate & 34.65 & - & - & $\mathrm{NC} 1, \mathrm{NC} 2, \mathrm{NC} 3, \mathrm{C} 1, \mathrm{C} 3$ & MS & - \\
\hline 27 & 2-Phenylethyl acetate & 35.4 & flower, honey, rose & - & $\mathrm{NC} 1, \mathrm{NC} 3$ & MS & - \\
\hline 28 & Monoethyl succinate & 38.62 & - & - & $\mathrm{NC} 1, \mathrm{NC} 2, \mathrm{NC} 3, \mathrm{C} 1, \mathrm{C} 3$ & MS & - \\
\hline
\end{tabular}


Table 1. Cont.

\begin{tabular}{|c|c|c|c|c|c|c|c|}
\hline Number & Compound & $\begin{array}{l}\text { Retention } \\
\text { Time (min) }\end{array}$ & Odor Quality a & $\begin{array}{l}\text { Kovats Retention } \\
\text { Index }{ }^{\mathrm{b}}\end{array}$ & Sample Found & Identification $^{c}$ & Reference \\
\hline \multicolumn{8}{|c|}{ Alcohols } \\
\hline 29 & 2-Methyl-1-propanol & 6.36 & apple, bitter, cocoa, wine & $1107^{\mathrm{b}}$ & $\mathrm{NC1}, \mathrm{NC3}$ & MS, IK & Chuenchomrat et al. (2008) \\
\hline 30 & 3,7-Dimethyl-1-octanol & 6.57 & - & - & $\mathrm{NC} 1, \mathrm{NC} 3$ & MS & - \\
\hline 31 & 1-Butanol & 7.21 & fruit & $1156^{\mathrm{b}}$ & NC2 & MS, IK & Chuenchomrat et al. (2008) \\
\hline 32 & 3-Penten-2-ol & 7.56 & - & - & All samples & MS & - \\
\hline 33 & 2-Butyl-1-Octanol & 9.26 & - & - & $\mathrm{NC} 1, \mathrm{NC} 3, \mathrm{C} 1, \mathrm{C} 2, \mathrm{C} 3$ & MS & - \\
\hline 34 & 3-Ethoxy-1-propanol & 10.37 & - & - & $\mathrm{C} 2$ & MS & - \\
\hline 35 & 2-Ethyl-1-hexanol & 12.52 & - & $>1361^{\mathrm{b}}$ & $\mathrm{C} 2$ & MS, IK & Chung et al. (1993) \\
\hline 36 & 1-Decanol, 2-hexyl- & 13.50 & - & - & NC2 & MS & - \\
\hline 37 & 2,3-Butanediol & 14.69 & - & $>1493^{b}$ & All samples & MS, IK & Chuenchomrat et al. (2008) \\
\hline 38 & 1,2-Propanediol & 15.1 & - & - & $\mathrm{NC} 2, \mathrm{C} 1, \mathrm{C} 2$ & MS & - \\
\hline 39 & Furfuryl alcohol & 17.13 & burnt, caramel, cooked & $>1493^{b}$ & All samples & MS, IK, STD & Chuenchomrat et al. (2008) \\
\hline 40 & 3-(Methylthio)-1-propanol & 18.65 & - & - & $\mathrm{C} 1, \mathrm{C} 2$ & MS & - \\
\hline 41 & 1,3-Propanediol & 20.67 & - & - & $\mathrm{C} 2$ & MS & - \\
\hline 42 & Benzyl alcohol & 23.54 & $\begin{array}{l}\text { sweet, flowery, boiled cherries, moss, } \\
\text { roasted bread, rose }\end{array}$ & $1943^{\mathrm{b}}$ & All samples & MS, IK & Chuenchomrat et al. (2008) \\
\hline 43 & Phenylethyl Alcohol & 24.58 & honey, spice, rose, flowery, caramel & $1997^{\mathrm{b}}$ & All samples & MS, IK & Jerković et al. (2012) \\
\hline 44 & Benzene propanol & 28.66 & - & - & All samples & MS & - \\
\hline 45 & p-Menthane-1,8-diol & 30.17 & - & - & $\mathrm{NC1}, \mathrm{NC} 3$ & MS & - \\
\hline 47 & 1-Phenyl-1-decanol & 58.78 & - & - & $\mathrm{NC1}, \mathrm{NC} 3$ & MS & - \\
\hline 48 & 3-(p-Hydroxyphenyl)-1-propanol & 58.99 & - & - & NC2 & MS & - \\
\hline \multicolumn{8}{|c|}{ Aldehydes } \\
\hline 49 & Benzaldehyde & 13.63 & $\begin{array}{l}\text { bitter almond, burnt sugar, cherry, malt, } \\
\text { roasted pepper }\end{array}$ & $>1500^{\mathrm{b}}$ & $\mathrm{C} 1, \mathrm{C} 3$ & MS, IK & Wanakhachornkrai \& Lertsiri (2003) \\
\hline 50 & 4-Methyl-benzaldehyde & 16.8 & - & $>1500^{\mathrm{b}}$ & $\mathrm{NC1}, \mathrm{NC2}, \mathrm{NC} 3$ & MS, IK & Wanakhachornkrai \& Lertsiri (2003) \\
\hline 51 & 3-Methyl-benzaldehyde & 37.35 & Alkan & $>1500^{\mathrm{b}}$ & $\mathrm{NC} 1, \mathrm{NC} 3, \mathrm{C} 2$ & MS, IK & Wanakhachornkrai \& Lertsiri (2003) \\
\hline 52 & Dodecane & 7.823 & - & - & All samples & MS & - \\
\hline 53 & 4,6-Dimethyl-dodecane & 7.90 & - & $1200^{\mathrm{b}}$ & $\mathrm{C} 1, \mathrm{C} 3, \mathrm{NC} 1, \mathrm{NC} 3$ & MS, IK & Chung et al. (1993) \\
\hline 54 & 2,3,6,7-Tetramethyl-octane & 8.064 & - & $1300^{\mathrm{b}}$ & $\mathrm{C} 1, \mathrm{C} 3$ & MS, IK & Chung et al. (1993) \\
\hline 55 & 5-Methyl-tridecane & 9.67 & - & - & $\mathrm{NC} 1, \mathrm{NC} 3, \mathrm{C} 1, \mathrm{C} 3$ & MS & - \\
\hline
\end{tabular}


Table 1. Cont.

\begin{tabular}{|c|c|c|c|c|c|c|c|}
\hline Number & Compound & $\begin{array}{l}\text { Retention } \\
\text { Time (min) }\end{array}$ & Odor Quality a & $\begin{array}{l}\text { Kovats Retention } \\
\text { Index }\end{array}$ & Sample Found & Identification ${ }^{c}$ & Reference \\
\hline \multicolumn{8}{|c|}{ Alkanes } \\
\hline 56 & Tetradecane & 10.54 & - & $1400^{\mathrm{b}}$ & All samples & MS, IK & Jerković et al. (2012) \\
\hline 57 & 3,3-Dimethyl-heptane & 10.61 & - & - & $\mathrm{NC} 1, \mathrm{NC} 3$ & MS & - \\
\hline 58 & Farnesan & 11.13 & - & - & $\mathrm{NC} 1, \mathrm{NC} 3, \mathrm{C} 2$ & MS & - \\
\hline 59 & 3-Ethyl-3-methylheptane & 15.30 & - & - & All samples & MS & - \\
\hline 60 & Nonadecane & 17.80 & - & $1900^{\mathrm{b}}$ & All samples & MS, IK & Jerković et al. (2012) \\
\hline 61 & Eicosane & 12.48 & - & $2000^{b}$ & All samples & MS, IK & Chung et al. (1993) \\
\hline \multicolumn{8}{|c|}{ Furanic } \\
\hline 62 & 2,2,3,3,4,4-Hexamethyltetrahydrofuran & 8.905 & - & - & $\mathrm{C} 1, \mathrm{C} 3$ & MS & - \\
\hline 63 & Furfural & 12.30 & $\begin{array}{l}\text { almond, baked potatoes, bread, burnt, } \\
\text { spice }\end{array}$ & $1493^{b}$ & $\mathrm{C} 1, \mathrm{C} 2, \mathrm{C} 3$ & MS, IK, STD & Chuenchomrat et al. (2008) \\
\hline 64 & 5-Methylfurfural & 12.38 & - & $>1493^{\mathrm{b}}$ & $\mathrm{C} 1, \mathrm{C} 2, \mathrm{C} 3$ & MS, IK & Chuenchomrat et al. (2008) \\
\hline 65 & Acetylfuran & 13.20 & balsamic, cocoa, coffee & - & $\mathrm{C} 1, \mathrm{C} 3$ & MS & - \\
\hline 66 & 2-Furoate-methyl & 14.88 & fruit & - & All samples & MS, STD & - \\
\hline 67 & Furan, 2-(1,2-diethoxyethyl)- & 21.07 & - & - & All samples & MS, IK & - \\
\hline 68 & 2-(Hydroxyacetyl)furan & 27.83 & - & - & $\mathrm{NC1}, \mathrm{NC} 3$ & MS & - \\
\hline 69 & $\begin{array}{l}\text { 2,5-Dimethyl-2-(2-tetrahydrofuryl) } \\
\text { tetrahydrofuran }\end{array}$ & 30.37 & - & - & All samples & MS & - \\
\hline 70 & HMF & 41.99 & $\begin{array}{l}\text { almond, baked potatoes, bread, } \\
\text { burnt, spice }\end{array}$ & $>1493^{b}$ & $\mathrm{C} 1, \mathrm{C} 2, \mathrm{C} 3$ & MS, IK, STD & Chuenchomrat et al. (2008) \\
\hline 71 & Furan, 2-(1,2-dimethoxyethyl)- & 32.16 & - & - & $\mathrm{NC} 2$ & MS & - \\
\hline 72 & \multicolumn{6}{|c|}{ Ketones } & - \\
\hline 73 & 3(2H)-Furanone, dihydro-2-methyl & 8.8 & nuts & $1207^{\mathrm{b}}$ & $\mathrm{C} 1, \mathrm{C} 2, \mathrm{C} 3$ & MS, IK & Wanakhachornkrai \& Lertsiri (2003) \\
\hline 74 & Acetoin & 9.057 & butter, creamy, green pepper & $1306^{\mathrm{b}}$ & $\mathrm{NC} 1, \mathrm{NC} 2, \mathrm{C} 1, \mathrm{C} 2, \mathrm{C} 3$ & MS, IK & Chuenchomrat et al. (2008) \\
\hline 75 & 2-Cyclopenten-1-one & 10.26 & - & - & $\mathrm{C} 1, \mathrm{C} 3$ & MS & - \\
\hline 76 & 2-Butanone, 3,4-epoxy-3-ethyl & 13.18 & - & - & NC2 & MS & - \\
\hline 77 & 2(3H)-Furanone, dihydro-5-methyl- & 15.87 & - & $>1500^{\mathrm{b}}$ & $\mathrm{NC} 2, \mathrm{C} 1, \mathrm{C} 2, \mathrm{C} 3$ & MS, IK & Wanakhachornkrai \& Lertsiri (2003) \\
\hline 78 & $\gamma$-Butyrolactone & 16.394 & caramel, cheese, roasted nut & $1610^{\mathrm{b}}$ & $\begin{array}{l}\mathrm{NC} 1, \mathrm{NC} 2, \mathrm{NC} 3, \mathrm{C} 1 \\
\mathrm{C} 2, \mathrm{C} 3\end{array}$ & MS, IK & Márquez et al. (2010) \\
\hline 79 & $\begin{array}{l}\text { 2-Cyclopenten-1-one, } \\
\text { 2-hydroxy-3-methyl }\end{array}$ & 22.04 & - & - & $\mathrm{C} 1, \mathrm{C} 2, \mathrm{C} 3$ & MS & - \\
\hline 80 & $\alpha, \beta$-Angelica lactone & 17.75 & floral & - & $\mathrm{C} 1, \mathrm{C} 2$ & MS, IK & - \\
\hline
\end{tabular}


Table 1. Cont.

\begin{tabular}{|c|c|c|c|c|c|c|c|}
\hline Number & Compound & $\begin{array}{l}\text { Retention } \\
\text { Time (min) }\end{array}$ & Odor Quality a & $\begin{array}{l}\text { Kovats Retention } \\
\text { Index }{ }^{b}\end{array}$ & Sample Found & Identification ${ }^{c}$ & Reference \\
\hline \multicolumn{8}{|c|}{ Ketones } \\
\hline 81 & 2,5-Dimethyl-4-hydroxy-3(2H)-furanone & 22.96 & burnt, caramel, cotton candy, honey & $2024^{\mathrm{b}}$ & $\mathrm{C} 1, \mathrm{C} 3$ & MS, IK & Fuhrmann \& Grosch (2002) \\
\hline 82 & Furyl hydroxymethyl ketone & 27.51 & - & - & $\mathrm{NC} 3, \mathrm{C} 1, \mathrm{C} 2, \mathrm{C} 3$ & MS & - \\
\hline 83 & $\begin{array}{c}\text { 2(3H)-Furanone, } \\
\text { dihydro-3-hydroxy-4,4-dimethyl }\end{array}$ & 28.34 & - & - & $\mathrm{C} 1, \mathrm{C} 3$ & MS & - \\
\hline 84 & $\begin{array}{l}\text { Ethanone, } \\
\text { 1-(2,6-dihydroxy-4-methoxyphenyl) }\end{array}$ & 39.39 & - & - & NC2 & MS & - \\
\hline 85 & $\begin{array}{l}\text { Ethanone, } \\
\text { 1-(4-hydroxy-3,5-dimethoxyphenyl) }\end{array}$ & 54.24 & - & - & NC2 & MS & - \\
\hline \multicolumn{8}{|c|}{ Phenols } \\
\hline 86 & p-Guaiacol & 23.06 & burnt, phenol, wood & $>1500^{\mathrm{b}}$ & NC2 & MS, IK & Wanakhachornkrai \& Lertsiri (2003) \\
\hline 87 & p-Methylguaiacol & 26.06 & phenol & $>1500^{\mathrm{b}}$ & NC2 & MS, IK & Wanakhachornkrai \& Lertsiri (2003) \\
\hline 88 & 3-Methyl phenol & 29.93 & - & - & NC2 & MS & - \\
\hline 89 & Phenol, 2-methyl-5-(1-methylethyl) & 32.31 & caraway, spice, thyme & $2189^{\mathrm{b}}$ & NC2 & MS, IK & Jerković et al. (2012) \\
\hline 90 & 2,4-Di-tert-butylphenol & 36.67 & - & - & All samples & MS & - \\
\hline 91 & Phenol, 2-(5-isoxazolyl) & 45.90 & - & - & NC2 & MS & - \\
\hline 92 & Eugenol & 45.31 & burnt, clove, spice & - & NC2 & MS, STD & - \\
\hline 93 & Phenol, 2-(2-methylpropyl) & 51.53 & - & - & NC2 & MS & - \\
\hline 94 & 4-(2-Hydroxyethyl) phenol & 54.59 & - & - & $\mathrm{C} 1, \mathrm{C} 3$ & MS & - \\
\hline \multicolumn{8}{|c|}{ Pyrans } \\
\hline 95 & 2H-Pyran-2,6(3H)-dione & 27.26 & - & - & $\mathrm{NC1}, \mathrm{NC} 3$ & MS & - \\
\hline 96 & 2-Pentoxy-tetrahydropyran & 28.10 & - & - & $\mathrm{NC1}, \mathrm{NC} 3$ & MS & - \\
\hline 97 & $\begin{array}{c}\text { 4H-Pyran-4-one, } \\
\text { 2,3-dihydro-3,5-dihydroxy-6-methyl }\end{array}$ & 35.27 & - & - & $\mathrm{NC} 1, \mathrm{NC} 2, \mathrm{NC} 3$ & MS & - \\
\hline 98 & $\begin{array}{l}\text { Pyrrolo[1,2-a] pyrazine-1,4-dione, } \\
\text { hexahydro-3-(2-methylpropyl) }\end{array}$ & 60.62 & - & - & $\mathrm{C} 1, \mathrm{C} 2, \mathrm{C} 3$ & MS & - \\
\hline \multicolumn{8}{|c|}{ Others } \\
\hline 99 & m-Dioxane, 2-methyl & 5.96 & - & - & $\mathrm{C} 2$ & MS & - \\
\hline 100 & p-Dichlorobenzene & 11.78 & - & - & $\mathrm{NC1}, \mathrm{NC} 3$ & & - \\
\hline 101 & m-Di-tert-butylbenzene & 11.28 & - & - & $\mathrm{C} 1, \mathrm{C} 2, \mathrm{C} 3$ & MS & - \\
\hline 102 & 6,7-Dihydro-7-hydroxylinalool & 26.69 & - & - & $\mathrm{NC1}, \mathrm{NC} 3$ & MS & - \\
\hline 103 & 4-Acetoxy-3-methoxystyrene & 33.29 & - & - & $\mathrm{NC1}, \mathrm{NC} 3$ & MS & - \\
\hline 104 & Ethyl linoleate & 60.85 & - & - & All samples & MS & - \\
\hline
\end{tabular}

${ }^{a}$ Flavor notes reported (Flavor and Extract Manufacturers Association (FEMA)); ${ }^{\mathrm{b}}$ obtained from literature; ${ }^{\mathrm{c}}$ identification method: MS $=$ mass spectrometry, IK $=\mathrm{Kovats}$ index, $\mathrm{STD}=$ pure compound (standard). 


\subsubsection{Esters}

Esters ethyl orthoformate (17), ethyl butanoate (18), ethyl lactate (20), ethyl palmitate (26), among others esters were found in most tequila vinasses samples (NC and C).

\subsubsection{Alcohols}

Alcohols 2-methyl-1-propanol (29), 1-butanol (31), 2,3-butanediol (37), furfuryl alcohol (39), benzyl alcohol (42), phenylethyl alcohol (43), benzenepropanol (44), and others (Table 1) were found in the present work. Their concentrations ranged from 1.6-977.95 mg/L (NC and C processes).

In this research, furfuryl alcohol (39), benzyl alcohol (42) and phenylethyl alcohol (43) were identified and quantified in all vinasse samples (Figure 1). Furfuryl alcohol in vinasses from the $C$ process presented significantly higher concentrations $(3.76-16.25 \mathrm{mg} / \mathrm{L})$ than those from the NC process $(p<0.05)$. The vinasse $\mathrm{C} 1$ showed the highest concentration $(16.26 \mathrm{mg} / \mathrm{L})$. Benzyl alcohol was present in all the samples, showing significant differences $(p<0.05)$ between vinasses from the NC and C processes. The concentrations ranged from $3.42-46.6 \mathrm{mg} / \mathrm{L}$. Among them, the NC2 vinasse had the highest concentration of benzyl alcohol. Phenylethyl alcohol was found in both processes ranging from $366.41-470.92 \mathrm{mg} / \mathrm{L}$, with significant differences $(p<0.05)$ between both kinds of vinasse evaluated. The highest concentration was found in the C 3 vinasse (Figure 1).

\subsubsection{Aldehydes}

Only three aldehydes were detected in tequila vinasses: benzaldehyde (49), benzaldehyde, 4-methyl (50), and benzaldehyde, 3-methyl (51) (Table 1), regardless of the process (NC or C).

\subsubsection{Alkanes}

Similarly, 10 alkanes were identified in the vinasses evaluated regardless of the process involved: dodecane (52), tetradecane (56), nonadecane (60), and eicosane (61) (Table 1).

\subsubsection{Furanic Compounds}

Eleven different furanic compounds were identified in tequila vinasses, 10 in the $C$ vinasses and five in the NC vinasses. Furfural (63), 5-methylfurfural (64), acetylfuran (65), HMF (70) and furan,2-ethoxy-4-ethyl-2,3-dihydro (72) were found only in the $C$ vinasses, while 2-furoate-methyle (66), furan, 2-(1,2-diethoxyethyl)- (67) and 2,5-dimethyl-2(2-tetrahydrofuryl) tetrahydrofuran (69) were found in all the vinasses (Table 1 ).

Furfural was found in C1 and C3 (52.11 and $53.57 \mathrm{mg} / \mathrm{L}$, respectively); HMF presented the highest level in the C3 vinasse (347.61 mg/L) (Figure 1).

\subsubsection{Ketones}

Thirteen ketones were identified in the vinasses. Ten were mostly found in the $C$ vinasses, while only seven were found in some NC. $\gamma$-butyrolactone (78) was identified and quantified in all TVs, showing significantly higher concentration in the $C$ vinasses $(p<0.05)$ than in the NC vinasses. The concentration range was $1.5-56.78 \mathrm{mg} / \mathrm{L}$, where vinasse $\mathrm{C} 1$ presented the highest amount (Figure 1).

\subsubsection{Phenols}

Nine phenols were identified in the vinasses. p-Guaiacol (86), p-methylguaiacol (87), 3-methylphenol (88), eugenol (92), among others, were detected in the NC vinasses (Table 1). The 2,4-di-tert-butylphenol (90) was found in all the vinasses. The NC vinasses had a significantly lower concentration (11.20-21.35 mg/L) than the $C$ vinasses (4.23-87.44 mg/L). The highest presence of phenolic compounds (eugenol, p-guaiacol, 4-(2-hydroxyethyl) phenol) was observed in NC2 vinasse (Figure 1). 


\subsubsection{Pyrans}

Four pyrans were detected in the evaluated vinasses: (2H-pyran-2,6(3H)-dione (95), 2-pentoxy-te trahydropyran (96), 4H-pyran-4-one,2,3-dihydro-3,5-dihydroxy-6-methyl (97), and pyrrolo[1,2-a] pyrazine-1,4-dione (98) (Table 1). The latter was found only in the $C$ vinasses while the others were found in the NC vinasses.

\subsection{Principal Component Analysis (PCA)}

Principal component analysis (PCA) was used to determine the main sources of variability of the data sets and establish the relationship between tequila vinasses (objects) and volatile compounds (variables) [35]. PCA facilitated the interpretation in this study. The analysis allowed us to identify what volatile compounds were correlated with the kind of vinasse (NC or C). The two principal components (PCs) were enough to explain $60 \%$ of total variability from the data set, $32.29 \%$ and $28.09 \%$ by PC1 and PC2, respectively (Figure 2).

The PCs showed four distinct groups (Figure 2). The PC1 separated the volatile compounds according to the kind of vinasse. Vinasses from the cooking process were found in the positive side of the PC1 axis. Also, on this side, volatile compounds that correlate strongly with those vinasses are found, e.g., acetic acid (1), furfuryl alcohol (39), and furan compounds such as furfural (63), acetylfuran (65), 2-furoate-methyl (66), and HMF (70), among others. However, in the negative side of PC1, two groups were detected: the first includes NC1 and NC3 related to butyric acid (3), caproic acid (6), hendecanoic acid (11), among others; the second includes, NC2, which was correlated with phenolic compounds like p-guaiacol (86), p-methylguaiacol (87), 3-methyl phenol (88) eugenol (92), among others.

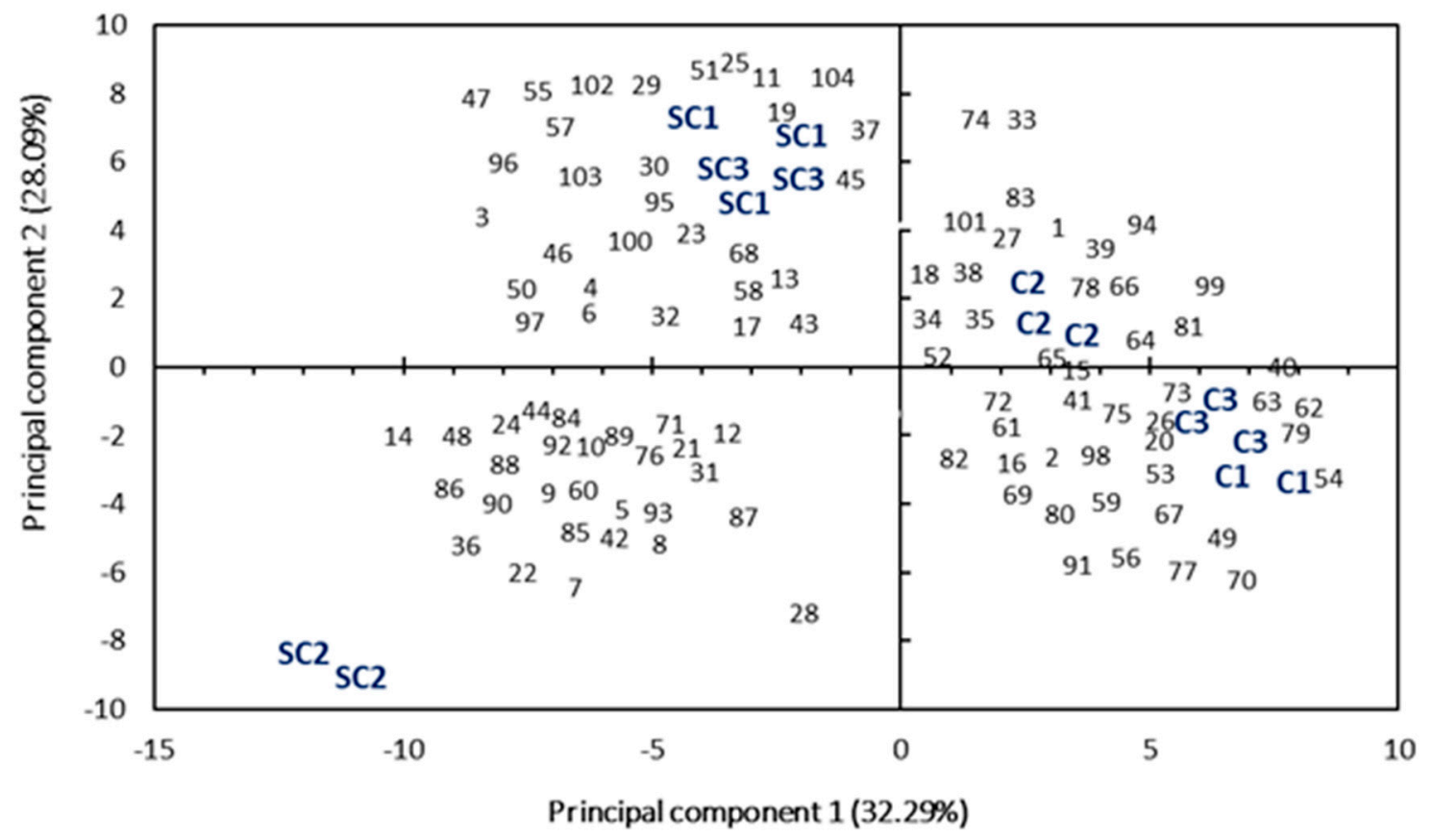

Figure 2. Principal component analysis (PCA), loadings (volatile compounds), and score plot (NC and $\mathrm{C}$ processes) of PC1 and PC2, from all volatile compounds in treatments.

\section{Discussion}

The identification of approximately $37 \%$ of the compounds in the present work is in agreement with previous work published with similar matrices, such as cooked agave juice, tequila beverage, and sugarcane vinasses [27-30]. This work focuses on the volatile compounds found in higher concentrations or with inhibitory potential for the biological process in the vinasse treatment. 


\subsection{Organic Acids}

Some organic acids found in tequila vinasses have been previously reported in similar matrices (i.e., tequila, cooked agave juice, and sugarcane vinasses) by other studies. For instance, acetic, butyric, isobutyric, valeric, palmitic, and myristic acids have been reported in tequila by Prado-Jaramillo et al. [30]. Likewise, Mancilla-Margalli and López [29] published the existence of acetic, butyric, valeric, caproic, oenanthic, caprylic and lauric acids in cooked agave juice. Also, Fagier et al. [27] reported the presence of palmitic acid in sugarcane vinasses. Lima et al. [28] identified lauric, myristic, and palmitic acids in hydrolyzed sugarcane vinasses.

The presence of organic acids in high concentrations confer toxicity to the vinasses, hindering their treatment by biological process or their exploitation via biohydrogen production. Acetic and butyric acids have negatives effects in the DF process of acetic acid-decreased Hmax (maximum potential of $\mathrm{H} 2$ production) and Rmax (maximum $\mathrm{H} 2$ production rate) in batch production [36]. In addition, Wang, Wan, and Wang [37] reported inhibitory effects for Hmax and Rmax in batch conditions, using $6 \mathrm{~g} / \mathrm{L}$ and $8 \mathrm{~g} / \mathrm{L}$ of acetic and butyric acids, respectively. In this work, these acids were found in both processes studied, NC $(146.14 \mathrm{mg} / \mathrm{L})$ and C $(512.47 \mathrm{mg} / \mathrm{L})$, at lower concentration than those reported in the literature $[34,36,37]$. Nonetheless, a synergistic effect might occur, as both are present in the vinasses, which can boost their potential individual inhibitory effects. Franden et al. (2013) demonstrated that the concomitant presence of acetic and formic acids (IC25 $=50.3 \mathrm{mg} / \mathrm{L}$ ) inhibited the growth of Zymomonas mobilis [38].

Organic acids may be either protonated or unprotonated, both species inhibiting biohydrogen production [34]. They can uncouple hydrogen-producing bacteria (HPB) growth in two ways: (i) on the one hand, the nonpolar un-dissociated form can penetrate cell membrane HPB whereby they dissociate due to higher intracellular $\mathrm{pH}$, releasing protons in the cell cytoplasm; as a result, this creates a $\mathrm{pH}$ imbalance and decreases intracellular $\mathrm{pH}$, producing a reduction in the available energy used in HPB growth; (ii) on the other hand, if the polar-dissociated part of organic acids is present in the fermentative hydrogen production system at a high concentration, the ionic strength in the solution will be increased, causing HPB growth inhibition and cell lysis [34,36,37,39].

\subsection{Esters}

Prado-Jaramillo et al. [30] identified ethyl butyrate, ethyl caprate, ethyl caproate, ethyl ethanoate, ethyl furoate, among other esters, in tequila. Likewise, Fagier et al. [27] found palmitic acid methyl ester in vinasses from sugarcane distillation. Similarly, in hydrolyzed sugarcane vinasses, Lima et al. [28] found ethyl myristate, ethyl palmitoleate, ethyl palmitate, 2-phenylethyl laurate, ethyl oleate, and ethyl stearate.

\subsection{Alcohols}

In a previous study performed by Prado-Jaramillo et al. [30] in tequila, the alcohols reported were 1-decanol, 1-dodecanol, 1-heptanol, butanol, isobutanol, phenylethyl alcohol, n-propanol, among others. Similarly, Mancilla-Margalli and López [29] found 1-butanol, 3-methyl-1-butanol, 1-hexanol, 1-octen-3-ol, 1,2-butanediol, 1,3-butanediol, 1,2-ethanediol, benzyl alcohol, phenylethyl alcohol in cooked agave juice. Also, they quantified benzyl alcohol and phenylethyl alcohol concentration, which were $3.78 \mathrm{mg} / \mathrm{L}$ and $4.58 \mathrm{mg} / \mathrm{L}$, respectively. Additionaly, Fagier et al. [27] detected the presence of 2-phenyl ethanol in sugarcane vinasses. In other works, the presence of 2-phenylethanol, pentadecan-1-ol, and hexadecane-1-ol was identified in hydrolyzed sugarcane vinasse [28].

It is known that furfuryl alcohol might cause a significant membrane leakage in some bacteria (i.e., Escherichia coli) and exhibits synergism when present along with other inhibitors of microbial growth [40]. Currently, there is no available information about the inhibitory nature of the identified alcohols on the DF process. 


\subsection{Aldehydes}

Prado-Jaramillo et al. [30] reported the presence of aldehydes in tequila, such as benzaldehyde, benzene acetaldehyde, hexanaldehyde, myristaldehyde, nonaldehyde, among others. Likewise, Mancilla-Margalli and López [29] detected benzaldehyde, phenylacetaldehyde, and 4-hydroxybenzaldehyde in cooked agave juice. Furthermore, pentadecanal was found in hydrolyzed sugarcane vinasse by Lima et al. [28].

It is known that the presence of some aldehydes (i.e., 4-hydroxybenzaldehyde) has been reported to impair the growth of an ethanologenic Escherichia coli B (LY01) at concentrations of $600 \mathrm{mg} / \mathrm{L}$, where a 50\% growth inhibition was observed [41]. Aldehydes inhibit some pathways such as glycolysis and fermentation [41-43]. Therefore, their presence in tequila vinasses could be considered as a potential inhibitor for DF in hydrogen production.

\subsection{Alkanes}

Several hydrocarbons have been detected in tequila by Prado-Jaramillo et al. [30], who reported the presence of dodecane, eicosane, heptadecane, hexadecane, nonadecane, tetradecane, tricosane, and others. Furthermore, Fagier et al. [27] reported the presence of one cycloalkane (1,1,4,4-tetramethyl-2,5-dimethylenecyclohexane) in sugarcane vinasses. In addition, Lima et al. [28] detected heptacosane in hydrolyzed sugarcane vinasse.

The chemical group of alkanes has been not reported as potential inhibitors of the DF process. However, the presence of some hydrocarbons (i.e., alkanes, branched alkanes, among others) in soils can alter soil enzymatic activities and microbial biomass carbon [44,45]. Also, they may inhibit some bacterial populations [46].

\subsection{Furanic Compounds}

The presence of some furanic compounds has been previously reported in tequila and cooked agave juice. Prado-Jaramillo et al. [30] identified 10 furanic compounds in tequila from the cooking process, such as 1-furan-2-yl ethenone, 2-(1,2-diethoxyethyl) furan, furfural, 5-(hydroxymethyl) furfural (HMF), 5-methylfurfural, among others. Similarly, Mancilla-Margalli and López [29] identified eight furanic compounds in cooked agave juice, among which are furfural, HMF, methyl-2-furoate, 2-furanmethanol, and tetrahydro-2-methylfuran. Recently, furfural has also been identified in hydrolyzed sugarcane vinasses by Lima et al. [28].

Furanic compounds such as furfural and HMF have been reported as inhibitors during fermentative hydrogen production $[32,34,36,47]$. The presence of furfural and HMF can inhibit several enzymes (i.e., alcohol dehydrogenase and pyruvate dehydrogenase) in Saccharomyces cerevisiae at concentrations of 192-480 mg/L for furfural and 252-630 mg/L for HMF [48]. Even furfural is known to be more toxic than HMF for industrial catalysts, in E. coli and S. cerevisiae. Furthermore, ethanol production by E. coli B LYO1 is inhibited at concentrations $\geq 2.6 \mathrm{~g} / \mathrm{L}$ of furfural. This may be due to the fact that this compound has a direct effect on glycolytic and fermentative enzymes [41].

In agreement with previous studies performed in batch conditions for biohydrogen production, concentrations higher than 250 and $100 \mathrm{mg} / \mathrm{L}$ of furfural and HMF, respectively, directly affected Hmax and Rmax [32,36]. In this study, furfural concentration in vinasses was lower than the inhibitory concentration previously reported, but HMF concentration in tequila vinasses (C) was higher than that reported $[32,34,36]$. Also, both compounds in vinasses could increase the inhibitory effects.

Furfural and HMF are known to suppress cell growth, induce DNA damage, and inhibit several enzymes of the glycolytic and fermentative pathways (i.e., hexokinase, phosphofructokinase, triosephosphate, dehydrogenase, aldolase, among others) [32,34,48,49]. Furfural may decrease the activities of NADH-dependent enzymes involved in fermentation reactions; moreover, HMF and furfural reduction to furfuryl alcohol requires NADH in yeasts, which decrease $\mathrm{H}_{2}$ production. Additionally, $\mathrm{NADH}$ may reduce furan derivatives as it is oxidized to $\mathrm{NAD}_{+}$, leading to lower 
levels of NADH and lowering $\mathrm{H}_{2}$ production. Furthermore, HMF bears a hydroxyl group, which can bind to DNA nitrogen bases (specifically, adenine and thymine), causing DNA damage and mutations in many HPB [34,36,42,43]. In addition, it is known that furfural can inhibit fermentation and growth synergistically with phenols in E. coli and, when applied with acetic acid, can inhibit growth in S. cerevisiae [38].

\subsection{Ketones}

Some ketones have been found by Prado-Jaramillo et al. [30] in tequila, who reported acetoin, $\alpha$-angelica lactone, $\beta$-angelica lactone, 1-(2-hydroxyphenyl) ethenone, 2-furyl acetone, acetovanillone, among others. Furthermore, Mancilla-Margalli and López [29] reported the existence of five ketones in cooked agave juice: 2-hydroxy-2-butanone, 1-hydroxy-2-propanone, butyrolactone, cyclotene and $\beta$-damascenone. Moreover, the presence of one ketone (E-1-(3-hydroxy-2,6,6-trimethylcyclohex-1-enyl) but-2-en-1-one) was reported by Fagier et al. [27] in sugarcane vinasse.

There are no reports about ketones with potential inhibition for the DF process. In fact, Mills, Sandoval and Gill [40] state that ketones can be generated during the acidogenic stage, but are not considered as potential inhibitors because they are produced at low concentrations $(<0.05 \mathrm{~g} / \mathrm{L})$. However, there is still a lack of knowledge about the effect of ketones on the DF process.

\subsection{Phenol Compounds}

Some phenols have been previously reported by Prado-Jaramillo et al. [30] in tequila; like eugenol, carvacrol, phenol, thymol, and butylated hydroxyanisole. Furthermore, Fagier et al. [27] reported the presence of four phenols in sugarcane vinasses: 4-ethyl-3-methoxy phenol, 2,6-dimethoxy phenol, 3,4,5- trimethoxy phenol and 4-allyl-2,6-dimethoxy phenol.

Several studies have shown the inhibitory effects on the DF process caused by other phenolic compounds such as hydroxybenzoic acid, syringaldehyde and vanillin $[32,34,36,49,50]$. However, those phenols were not identified in tequila vinasses, and other phenols were found that may have other adverse effects. High concentrations $(0.12-50 \mathrm{mg} / \mathrm{L})$ of phenolic compounds can inhibit fungior bacteria-fermenting carbohydrates into ethanol, by deactivation of lignocellulose-hydrolyzing enzymes [51]. Phenolic compounds are more inhibitory than furan compounds and organic acids, as phenols can lead to precipitation and irreversible inhibition of lignocellulose-hydrolyzing enzymes [51,52]. Also, since phenols are the most abundant components in soils [53], these compounds may affect the pools and fluxes of soil nutrients by disturbing the communities of microbial decomposers. Generally, vinasses are disposed into soils without any treatment [10], which could cause a disturbance in soils by altering the natural concentration of phenols, thereby affecting soil microbiota and plants. Phenolics, depending on their concentration, have been found to either stimulate or inhibit spore germination. For instance, hyphal growth of saprophytic fungi and hyphal branching are altered by quercetin (30.22 mg/L), p-coumaric acid (16.4 mg/L), ferulic acid (19.41 mg/L), hydroxybenzoic acid (13.81 mg/L) [54-56]. Arbuscular mycorrhizal fungi colonization of asparagus roots is decreased by ferulic acid ( $>50 \mu \mathrm{g} / \mathrm{g}$ ) [55]. Also, other phenolic compounds (trans-Cinnamic acid and p-coumaric acid) inhibit growth of the etiolated seedling and seeding growth of lettuce [57]. Moreover, phenolic compounds present antimicrobial activity against Escherichia coli [58], but also against other Gram-negative and positive bacteria such as Salmonella typhimurium, Shigella dysenteriae, Oenococcus oen and Lactobacillus hilgardii by changing the cell's membrane permeability DNA binding [59,60], and as a consequence, affecting their ability to serve as selective barriers causing leakage and intracellular damage, leaving cells vulnerable to extracellular toxic compounds $[32,34,36,50]$. In the tequila vinasses phenolic compounds were found at 108.13-206.32 $\mathrm{g} / \mathrm{moL}$, which suggests that p-guaiacol, p-methylguaiacol, phenol, 3-methyl and 4-2(hydroxyethyl)phenol may negatively affect HPB 


\subsection{Pyrans}

Prado-Jaramillo et al. [30] detected the presence of one pyran (3,4-dihydro-2H-pyran) in tequila. Mancilla-Margalli and López [29] reported the presence of three pyrans, such as 2,3-dihydro-4(H)-pyran-4-one maltol, 2,3-dihydroxy-3,5-dihydro-6-methyl-4(H)-pyran-4-one, and 2,3-dihydro-2-methyl-4(H)-pyran-4-one in cooked agave juice. These suggest that pyranic compounds could be present in the vinasses independent of the cooking or not-cooking process.

There is no report about the impact of pyrans on the DF process. Although, $15 \mathrm{mg} / \mathrm{L}$, 5,6 dihydro-2(H)- pyran-2-one has been shown to inhibit growth, and biofilm formation of the Gram-negative bacteria Ralstonia solanacearum [61,62]. All this suggest that the biological processes in all matrices where vinasses are disposed (soil and water) are negatively influenced.

\subsection{Relationship between PCA and Not-Cooking (NC) and Cooking (C) Processes}

According to PCA, it can be inferred from $\mathrm{C} 1$ and $\mathrm{C} 3$ that thermal hydrolysis carried out by cooking the agave stems with autoclave show a significant effect on furan compounds formation, (i.e., furfural and HMF), which may inhibit subsequently the fermentative process. Fructans are insoluble in water at room temperature $\left(25^{\circ} \mathrm{C}\right)$ but are soluble at $>50^{\circ} \mathrm{C}$ [63]. Therefore, hydrolysis is required to obtain fermentable sugars. When the cooking process is carried out, sugars are subjected to a series of complex reactions, mainly caramelization, Maillard and oxidation-dehydration reactions [22]. These reactions are influenced by several factors, such as temperature and period of the cooking process. Furfural is produced by xylose dehydration at elevated temperatures and pressures $[34,64]$. HMF is generated during the cooking process because of the dehydration of fructose in the initial stages of the Maillard reaction $[16,65]$. The generation of furfural and HMF is continuously increased throughout the cooking process of agave juice [29]. In our research, C3 vinasse showed a higher presence of acetic acid, which is known to be a degradation product of the Maillard reaction of glucose and fructose [66].

During the not-cooking agave process, acidic hydrolysis is carried out at $80{ }^{\circ} \mathrm{C}$. NC2 vinasses showed a higher presence of phenolic compounds. They might be already present in the feedstock or generated during the initial stages of acid-thermal degradation (NC) of $[29,30]$. Also, the stems of Agave tequilana Weber var. Azul presented high contents of $\alpha$-cellulose $(65 \%)$, hemicellulose $(5.5 \%)$ and lignin (16.8\%) [66]; and when fructans hydrolysis is performed under acidic conditions, the splitting of $\beta-\mathrm{O}-4$ ether and other acid-labile linkages in lignin forms phenolic compounds [67]. Also, vinasses $\mathrm{NC} 1$ and NC3 presented a higher presence of organic acids than might be formed during hemicellulose acid-hydrolysis [68], contributing to the formation of phenolic compounds.

\section{Materials and Methods}

\subsection{Chemicals and Standards Used}

All experiments were performed with compounds standard grade and solvents high-performance liquid chromatography (HPLC) grade. 2,4-di-tert-butylphenol, 5-(hydroxymethyl) furfural (HMF), acetic acid, butyric acid, eugenol, formic acid, furfural, furfuryl alcohol, isobutyric acid, methyl-2-furoate, propionic acid, stearic acid and valeric acid standards were purchased from Sigma-Aldrich (Sigma-Aldrich, St. Louis, MO, USA). The HPLC-grade dichloromethane and methanol were supplied by Sigma-Aldrich. The anhydrous sodium sulfate was purchased from Fermont (Fermont, Monterrey, Mexico).

\subsection{Samples}

Vinasses were obtained from six tequila distilleries located in Tequila, Jalisco, Mexico. The tequila factories were selected from two types of agave juice extraction process, three of them were manufactured by using the traditional process (cooking agave stems) and were coded from $\mathrm{C} 1$ to $\mathrm{C} 3$; the other three come from a not cooking process and were labeled as NC1 to NC3. Twenty liters of vinasses 
from each industry were sampled after the distillation process was accomplished. Vinasses were kept at $4{ }^{\circ} \mathrm{C}$ until their analysis.

\subsection{Volatile Compound Extractions}

Volatile compounds were extracted by the liquid-liquid extraction method proposed by Prado-Jaramillo et al. [30] using dichloromethane. Vinasses were placed in a centrifuge tube (40-mL) and $10 \mathrm{~mL}$ of $\mathrm{CH}_{2} \mathrm{Cl}_{2}$ were added. Subsequently, the samples were shaken for $5 \mathrm{~min}$ and centrifuged for $10 \mathrm{~min}$ at $5000 \mathrm{rpm}$ and $10{ }^{\circ} \mathrm{C}$. The organic layer was separated and dried with anhydrous $\mathrm{Na}_{2} \mathrm{SO}_{4}$. All extracts were concentrated to a final volume of $1.5 \mathrm{~mL}$ with a rotatory evaporator IKA ${ }^{\circledR} \mathrm{RV} 10$ basic (IKA, Wilmington, NC, USA). The extracts were settled in suitable amber vials and preserved at $-19{ }^{\circ} \mathrm{C}$, until chromatographic analysis. Each vinasse sample was extracted and analyzed in triplicate.

\subsection{Separation and Identification of Volatile Compounds}

The volatile compounds were analyzed by a gas chromatography (GC) 6890N Network system (Agilent Technology, Santa Clara, CA, USA), coupled to a selective mass spectrometer detector 5975 (Agilent Technology, USA). Compound separations were performed using an HP-FFAP capillary column of $25 \mathrm{~m} \times 0.32 \mathrm{~mm}$ (i.d), coated with a $0.52 \mu \mathrm{m}$ film (Agilent Technologies, Santa Clara, CA, USA). Helium was used as carrier gas, using a $2 \mathrm{~mL} / \mathrm{min}$ of flow with an initial temperature of $40{ }^{\circ} \mathrm{C}$ for $5 \mathrm{~min}$. Followed by a temperature program of $20^{\circ} \mathrm{C} / \mathrm{min}$ to $100{ }^{\circ} \mathrm{C}$ for $1 \mathrm{~min}$, and by a second rate of $3{ }^{\circ} \mathrm{C} / \mathrm{min}$ to a final temperature of $230^{\circ} \mathrm{C}$ kept for $40 \mathrm{~min}$. The injector temperature was $220{ }^{\circ} \mathrm{C}$, and the injection mode was splitless. The selective mass detector operated an electronic impact ionization system at $70 \mathrm{eV}$, and at $260^{\circ} \mathrm{C}$. The identification of compounds was based on three criteria: (1) by comparing the mass spectra with the National Institute of Standards and Technology (NIST) library mass spectra; (2) by comparing the retention index with literature data; and (3) whenever possible, the identification was confirmed by using pure standards. Chromatograms obtained from the GC-MS analysis were integrated, and the peak areas were recorded for each identified compound. Quantification was performed by standard curves, obtained by preparing a solution with the different standard compounds in concentrations of $0.5,1,5,10,15$ and $20 \mathrm{mg} / \mathrm{L}$. Interpolation within a linear regression equation ( $R^{2}$ from 0.995 to 0.999 ) was used to calculate each compound concentration. When a commercial standard was not available, the quantification was achieved using a slope obtained for a standard of an analog compound that was structurally similar, but slightly different, as has been described elsewhere [69].

\subsection{Statistical Analysis}

All the statistical analyses were achieved with Statgraphics Centurion XVI (Statgraphics, The Plains, VA, USA). An analysis of variance (ANOVA) as well as Fisher's multiple-range tests of the minimal significant differences (LSD) were performed to find significant differences between $C$ and NC processes in the volatile profile. A PCA was used with the whole data.

\section{Conclusions}

The profile of volatile compounds was similar in cooking vinasses $(\mathrm{C})$ and not-cooking steam vinasses, but some differences were found in the concentration of volatile compounds, suggesting that the cooking process has an influence on the profile obtained in the vinasse composition. The cooking process increased the content of furanic compounds and organic acids, which are described as inhibitors of DF biohydrogen production from wastewater. The tequila vinasses obtained from a not-cooking process showed a higher presence of phenolic compounds. Although, the identified phenolic compounds have not been reported as inhibitors of the DF process, they may inhibit other biological processes in other matrices such as soil. Detailed description of the vinasses' composition could help in the development of any process to eliminate compounds that may interfere with biological processes to treat or use those or similar waste products around the world. 
Acknowledgments: The investigation presented in this paper was supported by the National Council for Science and Technology (CONACYT-BASIC SCIENCE) through project No. CB 2013-222677. In addition, Elizabeth Rodríguez-Félix thanks CONACYT for the masters scholarship No. 421959. The authors want to dedicate this manuscript to the memory of Gustavo Davila-Vazquez (R.I.P.), outstanding scientist, friend, academic tutor, co-author and co-worker in this research whose ideas triggered the basis for this and several investigations in this field, who stood out for his dedication and enthusiasm at every moment.

Author Contributions: Gustavo Davila-Vazquez (R.I.P) was the lead researcher in this project who conceived and designed the experiments. Elizabeth Rodríguez-Félix conducted the experiments and wrote the manuscript. Jacobo Rodríguez-Campos contributed with analytical methods (gas chromatography) and statistical analysis capacitation. Silva Maribel Contreras-Ramos and Erika Nahomy Marino-Marmolejo contributed with reagents/material/analytical tools, provided insightful suggestions on the work, and revised the paper.

Conflicts of Interest: The authors declare no conflict of interest.

\section{References}

1. Morin Couallier, E.; Salgado Ruiz, B.; Lameloise, M.-L.; Decloux, M. Usefulness of reverse osmosis in the treatment of condensates arising from the concentration of distillery vinasses. Desalination 2006, 196, 306-317. [CrossRef]

2. Zhang, P.J.; Zhao, Z.G.; Yu, S.J.; Guan, Y.G.; Li, D.; He, X. Using strong acid-cation exchange resin to reduce potassium level in molasses vinasses. Desalination 2012, 286, 210-216. [CrossRef]

3. Alves, P.R.L.; Natal-da-Luz, T.; Sousa, J.P.; Cardoso, E.J.B.N. Ecotoxicological characterization of sugarcane vinasses when applied to tropical soils. Sci. Total Environ. 2015, 526, 222-232. [CrossRef] [PubMed]

4. Moran-Salazar, R.G.; Sanchez-Lizarraga, A.L.; Rodriguez-Campos, J.; Davila-Vazquez, G.; Marino-Marmolejo, E.N.; Dendooven, L.; Contreras-Ramos, S.M. Utilization of vinasses as soil amendment: Consequences and perspectives. SpringerPlus 2016, 5, 1007. [CrossRef] [PubMed]

5. Díaz, B.; Gomes, A.; Freitas, M.; Fernandes, E.; Nogueira, D.R.; González, J.; Moure, A.; Levoso, A.; Vinardell, M.P.; Mitjans, M.; et al. Valuable Polyphenolic Antioxidants from Wine Vinasses. Food Bioprocess Technol. 2012, 5, 2708-2716. [CrossRef]

6. Cedeño, M.C. Tequila Production. Crit. Rev. Biotechnol. 1995, 15, 1-11. [CrossRef] [PubMed]

7. Méndez-Acosta, H.O.; Snell-Castro, R.; Alcaraz-González, V.; González-Álvarez, V.; Pelayo-Ortiz, C. Anaerobic treatment of Tequila vinasses in a CSTR-type digester. Biodegradation 2010, 21, 357-363. [CrossRef] [PubMed]

8. Robles-González, V.; Galíndez-Mayer, J.; Rinderknecht-Seijas, N.; Poggi-Varaldo, H.M. Treatment of mezcal vinasses: A review. J. Biotechnol. 2012, 157, 524-546. [CrossRef] [PubMed]

9. Rajagopal, V.; Paramjit, S.M.; Suresh, K.P.; Yogeswar, S.; Nageshwar, R.D.V.K.; Avinash, N. Significance of vinasses waste management in agriculture and environmental quality-Review. Afr. J. Agric. Res. 2014, 9, 2862-2873. [CrossRef]

10. López-López, A.; Davila-Vazquez, G.; León-Becerril, E.; Villegas-García, E.; Gallardo-Valdez, J. Tequila vinasses: Generation and full scale treatment processes. Rev. Environ. Sci. Bio/Technol. 2010, 9, 109-116. [CrossRef]

11. Decloux, M.; Bories, A.; Lewandowski, R.; Fargues, C.; Mersad, A.; Lameloise, M.L.; Bonnet, F.; Dherbecourt, B.; Osuna, L.N. Interest of electrodialysis to reduce potassium level in vinasses. Preliminary experiments. Desalination 2002, 146, 393-398. [CrossRef]

12. España-Gamboa, E.; Mijangos-Cortes, J.; Barahona-Perez, L.; Dominguez-Maldonado, J.; Hernández-Zarate, G.; Alzate-Gaviria, L. Vinasses: Characterization and treatments. Waste Manag. Res. 2011, 29, 1235-1250. [CrossRef] [PubMed]

13. Cruz-Salomón, A.; Meza-Gordillo, R.; Rosales-Quintero, A.; Ventura-Canseco, C.; Lagunas-Rivera, S.; Carrasco-Cervantes, J. Biogas production from a native beverage vinasse using a modified UASB bioreactor. Fuel 2016, 198, 170-174. [CrossRef]

14. Da Silva, M.A.; Griebeler, N.P.; Borges, L.C. Uso de vinhaça e impactos nas propriedades do solo e lençol freático (Use of stillage and its impact on soil properties and groundwater). Rev. Bras. Eng. Agríc. Ambient 2007, 11, 108-114. [CrossRef] 
15. Espinoza-Escalante, F.M.; Pelayo-Ortíz, C.; Navarro-Corona, J.; González-García, Y.; Bories, A.; Gutiérrez-Pulido, H. Anaerobic digestion of the vinasses from the fermentation of Agave tequilana Weber to tequila: The effect of $\mathrm{pH}$, temperature and hydraulic retention time on the production of hydrogen and methane. Biomass Bioenergy 2009, 33, 14-20. [CrossRef]

16. Waleckx, E.; Gschaedler, A.; Colonna-Ceccaldi, B.; Monsan, P. Hydrolysis of fructans from Agave tequilana Weber var. azul during the cooking step in a traditional tequila elaboration process. Food Chem. 2008, 108, 40-48. [CrossRef]

17. Valenzuela, A.G. The Tequila Industry in Jalisco, Mexico; University of Arizona: Tucson, AZ, USA, 2016.

18. Martínez, M.D.C.; Pérez, E.L. Análisis del Mercado Potencial del Tequila $100 \%$ Agave. PhD. Thesis, Instituto Politécnico Nacional, Mexico City, Mexico, 2008.

19. Vazquez-Landaverde, P.A.; Rodriguez-Olvera, M.G. Tequila processing and flavor. Am. Chem. Soc. 2012, 1104, 237-276. [CrossRef]

20. Salgado, O. Perspectivas Económicas de la Producción de Tequila vs. Tequila 100\% Agave; Universidad Autónoma de Querétaro: Queretaro, Mexico, 2012.

21. Cedeño Cruz, M.; Alvarez Jacobs, J. Production of tequila from agave: Historical influences and contemporary processes. In The Alcohol Textbook: A Reference for the Beverage, Fuel and Industrial Alcohol Industries; Nottingham University Press; Alltech Inc.: Nottingham, UK, 1999; pp. 225-241.

22. Villanueva-Rodríguez, S.; Rodríguez-Garay, B.; Prado-Ramírez, R.; Gschaedler, A. Tequila: Tequila Raw Material, Classification, Process, and Quality Parameters. In Encyclopedia of Food and Health (FOHE); Academic Press: Waltham, MA, USA, 2015; pp. 1-7.

23. Villanueva-Rodriguez, S.; Escalona-Buendia, H. Tequila and mezcal: Sensory Attributes and Sensory Evaluation; Woodhead Publishing Limited: Cambridge, UK, 2011; ISBN 9780857090515.

24. Buitrón, G.; Carvajal, C. Biohydrogen production from Tequila vinasses in an anaerobic sequencing batch reactor: Effect of initial substrate concentration, temperature and hydraulic retention time. Bioresour. Technol. 2010, 101, 9071-9077. [CrossRef] [PubMed]

25. González, C.; Durán, J.E. Producción de hidrógeno a partir del tratamiento anaerobio de vinazas en un reactor UASB. Tecnol. Marcha 2014, 27, 3-12. [CrossRef]

26. Buitrón, G.; Prato-Garcia, D.; Zhang, A. Biohydrogen production from tequila vinasses using a fixed bed reactor. Water Sci. Technol. 2014, 70, 1919-1925. [CrossRef] [PubMed]

27. Fagier, M.A.; Elmugdad, A.A.; Aziz, M.E.A.; Gabra, N.M. Identification of some Organic Compounds in Sugarcane vinasse by Gas Chromatography-Mass Spectrometry and Prediction of their Toxicity Using TEST Method. J. Chem. Pharm. Sci. 2015, 8, 899-905.

28. Lima, A.V.A.; Barbosa, M.A.S.; Cunha, L.C.S.; De Morais, S.A.L.; De Aquino, F.J.T.; Chang, R.; Do Nascimento, E.A. Volatile compounds obtained by the hydrodistillation of sugarcane vinasse, a residue from ethanol production. Rev. Virtual Quim. 2017, 9, 764-773. [CrossRef]

29. Mancilla-Margalli, N.A.; López, M.G. Generation of Maillard compounds from inulin during the thermal processing of Agave tequilana Weber var. azul. J. Agric. Food Chem. 2002, 50, 806-812. [CrossRef] [PubMed]

30. Prado-Jaramillo, N.; Estarrón-Espinosa, M.; Escalona-Buendía, H.; Cosío-Ramírez, R.; Martín-del-Campo, S.T. Volatile compounds generation during different stages of the tequila production process: A preliminary study. LWT-Food Sci. Technol. 2015, 61, 471-483. [CrossRef]

31. Chen, Y.; Cheng, J.J.; Creamer, K.S. Inhibition of anaerobic digestion process: A review. Bioresour. Technol. 2008, 99, 4044-4064. [CrossRef] [PubMed]

32. Quéménur, M.; Hamelin, J.; Barakat, A.; Steyer, J.; Carrere, H.; Trably, E. Inhibition of fermentative hydrogen production by lignocellulose-derived compounds in mixed cultures. Int. J. Hydrogen Energy 2012, 7, 3150-3159. [CrossRef]

33. De Sá, L.R.V.; De Oliveira Moutta, R.; Da Silva Bon, E.P.; Cammarota, M.C.; Ferreira-Leitão, V.S. Fermentative biohydrogen production using hemicellulose fractions: Analytical validation for C5 and C6-sugars, acids and inhibitors by HPLC. Int. J. Hydrogen Energy 2015, 40, 13888-13900. [CrossRef]

34. Bundhoo, M.A.Z.; Mohee, R. Inhibition of dark fermentative bio-hydrogen production: A review. Int. J. Hydrogen Energy 2016, 41, 6713-6733. [CrossRef]

35. Jolliffe, I.T. Principal Component Analysis. J. Technometrics 1988, 30, 487. [CrossRef]

36. Siqueira, M.R.; Reginatto, V. Inhibition of fermentative $\mathrm{H}_{2}$ production by hydrolysis byproducts oflignocellulosic substrates. Renew. Energy 2015, 80, 109-116. [CrossRef] 
37. Wang, B.; Wan, W.; Wang, J. Inhibitory effect of ethanol, acetic acid, propionic acid and butyric acid on fermentative hydrogen production. Int. J. Hydrog. Energy 2008, 33, 7013-7019. [CrossRef]

38. Franden, M.A.; Pilath, H.M.; Mohagheghi, A.; Pienkos, P.T.; Zhang, M. Inhibition of growth of Zymomonas mobilis by model compounds found in lignocellulosic hydrolysates. Biotechnol. Biofuels 2013, 6, 99. [CrossRef] [PubMed]

39. Ciranna, A.; Ferrari, R.; Santala, V.; Karp, M. Inhibitory effects of substrate and soluble end products on biohydrogen production of the alkalithermophile Caloramator celer: Kinetic, metabolic and transcription analyses. Int. J. Hydrogen Energy 2014, 39, 6391-6401. [CrossRef]

40. Mills, T.Y.; Sandoval, N.R.; Gill, R.T. Cellulosic hydrolysate toxicity and tolerance mechanisms in Escherichia coli. Biotechnol. Biofuels 2009, 2, 26. [CrossRef] [PubMed]

41. Zaldivar, J.; Martinez, A.; Ingram, L.O. Effect of selected aldehydes on the growth and fermentation of ethanologenic Escherichia coli. Biotechnol. Bioeng. 1999, 65, 24-33. [CrossRef]

42. Banerjee, N.; Bhatnagar, R.; Viswanathan, L. Inhibition of glycolysis by furfural in Saccharomyces cerevisiae. Eur. J. Appl. Microbiol. Biotechnol. 1981, 11, 226-228. [CrossRef]

43. Palmqvist, E.; Hahn-Hagerald, B. Fermentation of lignocellulosic hydrolysates. II: Inhibitors and mechanisms of inhibition mechanisms of inhibition. Bioresour. Technol. 2000, 74, 25-33. [CrossRef]

44. Abha, S.; Singh, C.S. Hydrocarbon Pollution: Effects on Living Organisms, Remediation of Contaminated Environments, and Effects of Heavy Metals Co-Contamination on Bioremediation. In Introduction to Enhanced Oil Recovery (EOR) Processes and Bioremediation of Oil-Contaminated Sites; INTECH: Rijeka, Croatia, 2012; pp. 185-206.

45. Alrumman, S.A.; Standing, D.B.; Paton, G.I. Effects of hydrocarbon contamination on soil microbial community and enzyme activity. J. King Saud Univ. Sci. 2015, 27, 31-41. [CrossRef]

46. Hamamura, N.; Ward, D.M.; Inskeep, W.P. Effects of petroleum mixture types on soil bacterial population dynamics associated with the biodegradation of hydrocarbons in soil environments. FEMS Microbiol. Ecol. 2013, 85, 168-178. [CrossRef] [PubMed]

47. Haroun, B.M.; Nakhla, G.; Hafez, H.; Nasr, F.A. Impact of furfural on biohydrogen production from glucose and xylose in continuous-flow systems. Renew. Energy 2016, 93, 302-311. [CrossRef]

48. Modig, T.; Lidén, G.; Taherzadeh, M.J. Inhibition effects of furfural on alcohol dehydrogenase, aldehyde dehydrogenase and pyruvate dehydrogenase. Biochem. J. 2002, 363, 769-776. [CrossRef] [PubMed]

49. Monlau, F.; Sambusiti, C.; Barakat, A.; Quéméneur, M.; Trably, E.; Steyer, J.P.; Carrère, H. Do furanic and phenolic compounds of lignocellulosic and algae biomass hydrolyzate inhibit anaerobic mixed cultures? A comprehensive review. Biotechnol. Adv. 2014, 32, 934-951. [CrossRef] [PubMed]

50. Lin, R.; Cheng, J.; Ding, L.; Song, W.; Zhou, J.; Cen, K. Inhibitory effects of furan derivatives and phenolic compounds on dark hydrogen fermentation. Bioresour. Technol. 2015, 196, 250-255. [CrossRef] [PubMed]

51. Tejirian, A.; Xu, F. Inhibition of enzymatic cellulolysis by phenolic compounds. Enzyme Microb. Technol. 2011, 48, 239-247. [CrossRef] [PubMed]

52. Qin, L.; Li, W.-C.; Liu, L.; Zhu, J.-Q.; Li, X.; Li, B.-Z.; Yuan, Y.-J. Inhibition of lignin-derived phenolic compounds to cellulase. Biotechnol. Biofuels 2016, 9, 70. [CrossRef] [PubMed]

53. Min, K.; Freeman, C.; Kang, H.; Choi, S.-U.; Min, K.; Freeman, C.; Kang, H.; Choi, S.-U. The Regulation by Phenolic Compounds of Soil Organic Matter Dynamics under a Changing Environment. Biomed Res. Int. 2015, 2015, 825098. [CrossRef] [PubMed]

54. Wacker, T.L.; Safir, G.R.; Stephens, C.T. Effects of ferulic acid on Glomus fasciculatum and associated effects on phosphorus uptake and growth of asparagus (Asparagus officinalis L.). J. Chem. Ecol. 1990, 16, 901-909. [CrossRef] [PubMed]

55. Fries, L.L.M.; Pacovsky, R.S.; Safir, G.R.; Siqueira, J.O. Plant growth and arbuscular mycorrhizal fungal colonization affected by exogenously applied phenolic compounds. J. Chem. Ecol. 1997, 23, 1755-1767. [CrossRef]

56. Lattanzio, V.; Lattanzio, V.M.T.; Cardinali, A.; Amendola, V. Role of phenolics in the resistance mechanisms of plants against fungal pathogens and insects. Phytochem. Adv. Res. 2006, 661, 23-67.

57. Li, H.H.; Inoue, M.; Nishimura, H. Interactions oftrans-cinnamic acid, its related phenolic allelochemicals, and abscisic acid in seedling growth and seed germination of lettuce. J. Chem. Ecol. 1993, 19, 1775-1787. [CrossRef] [PubMed] 
58. Heipieper, H.J.; Keweloh, H.; Rehm, H.J. Influence of phenols on growth and membrane permeability of free and immobilized Escherichia coli. Appl. Environ. Microbiol. 1991, 57, 1213-1217. [PubMed]

59. Alves, M.J.; Ferreira, I.C.F.R.; Froufe, H.J.C.; Abreu, R.M.V.; Martins, A.; Pintado, M. Antimicrobial activity of phenolic compounds identified in wild mushrooms, SAR analysis and docking studies. J. Appl. Microbiol. 2013, 115, 346-357. [CrossRef] [PubMed]

60. Campos, F.M.; Couto, J.A.; Hogg, T.A. Influence of phenolic acid on growth and inactivation of Oenococcus oeni and Lactobacillus hilgardii. J. Appl. Microbiol. 2003, 94, 167-174. [CrossRef] [PubMed]

61. Priou, S.; Aley, P.; Chujoy, E.; Lemaga, B.; French, E. Control Integrado de la Marchitez Bacteriana de la Papa; Food and Agriculture Orgnization of the United Nations: Rome, Italy, 1999.

62. Gallego, A.; Giordano, W.; Rosero, E.; Echeverri, F. Effect of furans and a Pyran on Several Quorum Sensing Factors in Ralstonia solanacearum. J. Microb. Biochem. Technol. 2016, 8, 1-5. [CrossRef]

63. Salazar-Leyva, J.A.; Osuna-Ruiz, I.; Rodríguez-Tirado, V.A.; Zazueta-Patrón, I.E.; Brito-Rojas, H.D. Optimization study of fructans extraction from Agave tequilana Weber azul variety. Food Sci. Technol. 2016, 36, 631-637. [CrossRef]

64. Rong, C.; Ding, X.; Zhu, Y.; Li, Y.; Wang, L.; Qu, Y.; Ma, X.; Wang, Z. Production of furfural from xylose at atmospheric pressure by dilute sulfuric acid and inorganic salts. Carbohydr. Res. 2012, 350, 77-80. [CrossRef] [PubMed]

65. Gomes, F.N.D.C.; Pereira, L.R.; Ribeiro, N.F.P.; Souza, M.M.V.M. Production of 5-hydroxymethylfurfural (HMF) via fructose dehydration: Effect of solvent and salting-out. Braz. J. Chem. Eng. 2015, 32, 119-126. [CrossRef]

66. Iñiguez-Covarrubias, G.; Díaz-Teres, R.; Sanjuan-Dueñas, R.; Anzaldo-Hernández, J.; Rowell, R. Utilization of by-products from the tequila industry. Part 2: Potential value of Agave tequilana Weber azul leaves. Bioresour. Technol. 2001, 77, 101-108. [CrossRef]

67. Jönsson, L.J.; Martín, C. Pretreatment of lignocellulose: Formation of inhibitory by-products and strategies for minimizing their effects. Bioresour. Technol. 2016, 199, 103-112. [CrossRef] [PubMed]

68. Verardi, A.; De Bari, I.; Ricca, E.; Calabrò, V. Hydrolysis of Lignocellulosic Biomass: Current Status of Processes and Technologies and Future Perspectives. In Bioethanol; INTECH: Rijeka, Croatia, 2012; p. 290.

69. Rodriguez-Campos, J.; Escalona-Buendía, H.B.; Contreras-Ramos, S.M.; Orozco-Avila, I.; Jaramillo-Flores, E.; Lugo-Cervantes, E. Effect of fermentation time and drying temperature on volatile compounds in cocoa. Food Chem. 2012, 132, 277-288. [CrossRef] [PubMed] 